Burnes B, Hughes M \& By RT, Reimagining Organisational Change Leadership, Leadership, 14 (2), pp. 141-158. Copyright (C) 2016 The Authors. Reprinted by permission of SAGE Publications. DOI: https://doi.org/10.1177/1742715016662188

\title{
REIMAGINING ORGANISATIONAL CHANGE LEADERSHIP
}

\author{
Bernard Burnes, Mark Hughes and Rune Todnem By ${ }^{1}$
}

\begin{abstract}
Reimagining organisational change leadership orthodoxy requires revisiting the seminal work of Kurt Lewin and James M. Burns. Being the $20^{\text {th }}$ century most influential organisational change and leadership scholars, both radically reimagined their respective fields. However, often misinterpreted, misunderstood and even misrepresented, their true recommendations were largely ignored. In this article we discuss why this is so. Despite three decades of transformation and organisational change leadership discourse, leadership is still in crisis. Working towards an alternative to the current orthodoxy, we reimagine organisational change leadership as a utilitarian consequentialist process.
\end{abstract}

Key words: Leadership; Followership; Ethics; Utilitarian consequentialist approach; Kurt Lewin; James M. Burns; Organisational change

\footnotetext{
${ }^{1}$ See Appendix 1 for author details.
} 


\section{Introduction}
"This process [leadership] is essentially a shared experience, a voyage through time, with benefits to be gained and hazards to be surmounted by the parties involved. A leader is not a sole voyager, but a key figure whose actions or inactions can determine others' well-being and the broader good... The leadership process is therefore especially fraught with ethical challenges" (Hollander, 1995:55).

Organisational leadership and change go hand in hand, and one is nothing without the other. Whilst on the one side leadership research and practice has experienced an increased scrutiny of ethics, change research and practice has arguably experienced the opposite with a worrying decline in support for ethical approaches (Burnes, 2014; Burnes and By, 2012; Dunphy et al., 2007; Gopalakrishnan et al., 2008; Jones et al., 2000; Stiglitz, 2010; Storey, 2010). When reimagining change leadership as an ethical process, we adopt a utilitarian consequentialist approach, which posits that the value of an action is dependent not on its intent, but its consequences for the majority of stakeholders (Blackburn 2008; Kaler 2000a; Pettit 2003). Given that organisations and those who formally lead them tend to be judged by their achievements rather than their intentions, an ethical consequentialist approach is highly appropriate.

Over the last 20 years or so, there has been a substantial increase in both individual consequentialism and illegal practices by formal leaders. Although it is not inevitable that the two go together, in many instances this does seem to have been the case (Burnes and By, 2012). We argue that one of the major reasons for this is the concomitant rise and widespread acceptance of a misinterpreted approach to transformational leadership, which has allowed formal leaders an enormous degree of freedom to act as they see fit and to reward themselves for the privilege (Burnes and By, 2012; Jenkins, 2016; Storey, 2010). We maintain that this is neither desirable nor inevitable, but arises from the lack of transparency regarding the role of leaders and the absence of effective internal and external scrutiny of their actions. What is required for the betterment of not only individual organisations and their stakeholders, but for society at large is an approach to change leadership that promotes openness, allows employees at all levels including management and formal leadership to challenge actions based on individual consequentialism, and enables stakeholders to hold their formal leaders accountable for their actions.

All leadership approaches are underpinned by a set of values (By and Macleod, 2009; Burnes and Jackson, 2011). Some, such as Lewin's Planned approach to change, built on his Four Pillars of Field Theory, Group Dynamics, Action Research and the Three-Step Model of Change, openly promote ethical behaviour. Others, such as the Emergent approach to change, are much less transparent and have more ambiguous ethical foundations (Burnes and By, 2012). The challenge with today's progressive organisational change leadership orthodoxy is that the past is largely forgotten or at best misrepresented in the race towards unknown futures (Burnes and Cooke, 2012). Kotter (1996: 186) in Leading Change, the most cited change leadership publication when gauged by Google Scholar (Hughes, 2015) 
concludes that “... I can say with some authority that people who are making an effort to embrace the future are a happier lot than those who are clinging to the past". Furthermore, he declares his irritation with corporate history, acknowledging that cleaning up historical artefacts creates an even longer change agenda, but that purging of unnecessary interconnections ultimately makes transformations much easier (Kotter, 1996). We do not share Kotter's (1996) belief in 'historical cleansing' (see Hughes, forthcoming for further discussion). In reimagining organisational change leadership we remember great social scientists and those contributions we fear have been misunderstood or distorted with the passage of time. We share Ciulla's (2008) belief that leadership studies requires a fusion of horizons in which we interpret the past to understand the present in order to be applied to the future. In this conceptual article, we begin to reimagine organisational change leadership as informed by the work of Lewin (1947 a, b) and Burns (1978), rather than the writings of Bass (1985) and Kotter (1995, 1996).

First, we explore the challenge of organisational change leadership. Second, we look at organisational change leadership as an ethical process. Third, we revisit the writings of Lewin (1947, a, b) and Burns (1978) which although not primarily focussed upon organisational change leadership, together offer a vision of reimagined organisational change leadership. In Kotter (1996) terminology, we '...cling to the past...', and our unashamedly appreciative historiography is the antithesis of historical cleansing. In discussion, we reflect upon why potential contributions of Lewin (1947, a, b) and Burns (1978) have largely been misrepresented and why the prescriptions of Bass $(1985)$ and Kotter $(1995,1996)$ became the orthodoxy that have endured for so long. Fourth, we reimagine what an approach to organisational change leadership might have looked like if Lewin (1947, a, b) and Burns (1978) had collaborated on developing an organisational change leadership model informing both theory and practice. In standing on the shoulders of these two giants, we continue their work by offering a more utilitarian consequentialist approach to ethical organisational change leadership philosophy. An approach which is more suitable to the challenges faced by organisations and individuals in the $21^{\text {st }}$ century, especially those concerning organisational and environmental sustainability (Savitz and Weber, 2014). The neoliberal values which have driven organisations and shaped leadership behaviour in the $20^{\text {th }}$ century are no longer appropriate. In a world where organisational values need to promote the Triple Bottom Line (TBL) - People, Planet and Profit (Elkington, 1999; Savitz and Weber, 2014) - leaders are required to change radically what they do and how they do it. Given that most organisations struggle just to achieve their economic objectives, the changes required to meet the TBL challenge are formidable. If they are to be achieved, organisations will have to go far beyond the relatively limited and tokenistic stance taken to initiatives such as Corporate Social Responsibility (CSR), and adopt a more utilitarian consequentialist approach to running their organisations (Lund-Thomsen and Lindgreen, 2014). This will require fundamental changes to both internal and external relationships and practices, which pose significant challenges for leaders and to prevalent models of leadership. In order to create more utilitarian consequentialist organisations, leaders themselves will have to adopt a more utilitarian consequentialist approach to leading, managing and changing their organisations (Burnes and By, 2012; Burnes and Cooke, 2012; Burnes and Jackson, 2011). Therefore, reimagining 
organisational change leadership is essential to how organisations will operate in the future.

\section{The challenge of organisational change leadership}

Whilst Burns (1978:2) suggested that "Leadership is one of the most observed and least understood phenomena on earth", Diaz-Saenz (2011) regards transformational leadership as the single most studied and debated idea within leadership studies over the last three decades. However, transformational leadership has wrongfully been interpreted as the transformation of subordinates (Haslam et al, 2011) rather than the organisational and societal transformation as intended by Burns (1978).

In terms of transforming organisations through leadership, it is Kotter's (1995, 1996) writings which have been the most influential if gauged by Google Scholar citation counts (Hughes, 2015). However, despite the frequency of citations, Kotter's $(1995,1996)$ accounts of leading have been widely criticised as portraying employees as resistors; ignoring ethics and power; focusing too much on a linear sequence of steps; ignoring the benefits of incremental change; downplaying history limiting learning; over-stressing leadership and communications; understressing the influence of organisational culture; and displaying a limited understanding of success and failure (Hughes, 2015). Parry (2011), in his contribution to The SAGE Handbook of Leadership highlighted the lack of rigour within the change leadership literature:

“Leadership and organizational change are inextricably intertwined. However, 'organizational change' has become an interest for organizational consultants more so than for empirical researchers. There are many more books and articles on practitioner or conceptual scholarship than on theoretical or empirical scholarship. Much of the practitioner work is case study-based, and anecdotal and not rigorous in its conduct" (Parry, 2011:57).

Parry (2011) acknowledged the prevalence of practitioner literature which masked the lack of anticipated theoretical/empirical work. Ford and Ford (2012) in The Leadership of Organization Change: A View from Recent Empirical Evidence, reviewed all organisation change leadership academic peer-reviewed articles identifying 27 articles between 1990 and 2010, subsequently excluding certain articles resulting in a final tally of 14 articles. They assessed the contributions made by these articles and concluded that:

“...we find, the available research equivocal and incomplete regarding both what constitutes effective leadership and the impact of change leaders' approaches, behaviors, and activities on change outcomes of any type" (Ford and Ford, 2012:22).

However, if we examine this issue through the lens of the average employee rather than the formal leader who is all too often subtracted from the notion of an employee, a different picture emerges. A number of studies over the years have 
pointed to the role of employee involvement and choice as key factors in change initiatives (Burnes, 2014). The clearest evidence for this comes from Oreg et al's (2011) article Change Recipients' Reactions to Organizational Change: A 60-Year Review of Quantitative Studies. Oreg et al's (2011) meta-analysis did not specifically look at the leadership of change, but they did conclude that:

\footnotetext{
"As a rule, change recipients who experienced high levels of participation tended to report higher readiness and acceptance of change, appraised change as less stressful and exhibited overall support for the change ... Participation during the change process was also linked with the experience of positive emotions, a greater understanding of the meaning of change, realizing possible gains associated with the change and greater involvement in implementing behavioral changes ... In addition, participation contributed to change recipients' sense of competence, improved interpersonal trust, and increased attachment to the organization" (Oreg et al, 2011:491).
}

Oreg et al (2011) found that employee participation was related to perceived procedural justice and trust in those leading change. Taken together, their findings can be seen to link successful change to the participative-democraticethical approach to change developed by Lewin and promoted by OD practitioners (Burnes and Cooke, 2012).

Therefore, whilst Parry (2011), Ford and Ford (2012), and Hughes (2015) challenge the evidential basis of many of the claims made for change leadership, others, notably Oreg at al (2011) and Burnes and Cook (2012) do argue that the Lewin/OD approach to change leadership does have empirical and theoretical support. The challenge lays in the notion that many believe to be on the right track with the current organisational change leadership orthodoxy. However, we believe the orthodoxy itself is flawed, and that an alternative is required.

\section{Organisational change leadership as an ethical process}

In both private and organisational lives, we judge the appropriateness of our own actions and those of others based on our ethical beliefs, i.e. what we judge to be good or bad behaviour, what we see as right or wrong (Jones et al. 2000). As Wines (2008: 484) commented: "At bedrock, those who profess ethics believe that human beings are autonomous moral actors capable of making meaningful choices".

Pettit (2003) and Wood-Harper et al (1996) note that writers on ethics can be divided into two philosophical groupings: consequentialists and nonconsequentialist. Consequentialists take a teleological perspective on ethics, maintaining that ethical values must be actively promoted and judged on their outcomes rather than intent. Hence, the consequentialist stance seems to be most closely in line with how organisations and their formal leaders are judged, i.e. not by what they set out to achieve, but by what they actually achieve. For example, those world leaders who signed up to the Paris climate change deal in December 2015 will be judged not by the fact that they signed the deal, but by whether or not it achieves the positive outcomes it promises (Hamilton, 2016). 
Similarly, after the Deep Water Horizon disaster (Goldenberg 2010), BP is not being judged by its intentions to reform its practices, but by the outcomes of those intentions. In the same way, after the 2008 financial crisis (Wearden et al, 2008), we judge the financial institutions not by their promises to behave better in future, but by the results of those promises.

Thiroux and Krasemann (2007) note that ethical consequentialism is further divided into three main subsets. First, altruistic consequentialism originates with the work of the philosopher Auguste Comte, who was writing in the $19^{\text {th }}$ century. He described altruism as the impartial pursuit of the welfare of others (Blackburn 2008; Comte 1875). From this perspective, leaders could be expected to sacrifice their own interests if not aligned to the interests of the overall majority of stakeholders.

Second, individual (egoistic) consequentialism originates from philosophical writings of Thomas Hobbes who, working in the $17^{\text {th }}$ century, argued that human nature is based on the egoistic pursuit of self-interest (Jones 1980). For those who support this variety of consequentialism, an action is ethical if it produces the best results for the individual who takes that action. Thus, leaders are acting ethically if they pursue their own self-interest.

Third, utilitarian consequentialism, though developed by Bentham (Goldworth 1983; Mertens and Dhillon 1999), Mill (2002) and Sidgwick (1981), it is Bentham's definition of utilitarianism that tends to hold sway: “...of the various possibilities open to us in any given case, we ought to choose that which will produce the greatest happiness (i.e. pleasure) to the greatest number" (Jones 1980: 368). In terms of leadership, this challenges the narrow self-interest - profit at any price philosophy of the neo-liberals who have dominated organisational thinking for the last 30 years or so (Stiglitz, 2010). Instead, utilitarianism is much more aligned with the thinking of the sustainability movement, which seeks to promote the 'Triple Bottom Line' philosophy - People, Planet and Profit (TBL) (Savita and Weber, 2014).

Applying the utilitarian consequentialism approach, leaders can still pursue their own self-interest, but this must be aligned with those of the majority of the stakeholders, including the needs of wider society. This utilitarian 'greatest good for the greatest number' perspective is most closely associated with the $18^{\text {th }}$ and $19^{\text {th }}$ century philosophers and social reformers Jeremy Bentham (Goldworth 1983), John Stuart Mill (2002) and Henry Sidgwick (1981).

In contrast, non-consequentialists adopt a deontological perspective on ethics, maintaining that whilst ethical values are important, ethical behaviour should be judged by intent, i.e. what those involved intended to happen and not by what actually happened (Wood-Harper et al, 1996). This view is most closely associated with the philosophers John Locke (1958) and Immanuel Kant (1873), writing in the $17^{\text {th }}$ and $18^{\text {th }}$ centuries respectively.

In considering organisational change leadership, we take a utilitarian consequentialist perspective, looking to see if leadership behaviour achieves the greatest good for the majority of stakeholders rather than the few (Kagan 1992). 


\section{Remembering Lewin and Burns}

“...Knowledge - what counts as 'true' - is the property of particular communities and thus that knowledge is never neutral or divorced from ideology" (Grint, 2008:109).

In this section we remember the work of two eminent scholars who together could have shaped our approach to organisational change leadership. However, possibly for the reasons Grint (2008) intimates, their work never became the orthodoxy. Although the writings of Lewin (1947 a, b) and Burns (1978) were decades apart and they drew upon very different academic disciplines, in combination they offer a means to reimagine organisational change leadership.

\section{Remembering Lewin}

Lewin $(1890$ - 1947) has been acknowledged as the intellectual father of the Planned approach to change (Schein, 1988) and the founder of the Organization Development movement (OD), which is still, arguably, the most influential approach to organisational change (Burnes, 2004, 2007, Burnes and Cooke, 2013). Lewin had a strong commitment to resolving social conflict. This originated with the anti-Semitism he experienced as a Jew growing up in Germany in the early $20^{\text {th }}$ century. In 1933, when Hitler came to power, Lewin moved to the USA. The racial, religious and industrial strife he found there acted as further spur to his commitment to addressing social conflict. Out of this came Lewin's three major contributions to OD:

- His Four Pillars of Planned change comprising Field Theory, Group Dynamics, Action Research and the Three-Step Model of Change (Burnes, 2004, 2007).

- Showing how psychological experiments designed to study group behaviour in the laboratory could be utilised in the real world (Dent, 2002; Highhouse, 2007).

- A set of radical values. As Mirvis (2006: 77) commented, 'OD was birthed with utopian aspirations. Democracy and freedom were central to Lewin's work'. For Lewin, overcoming social conflict, whether it be religious, political or industrial, went hand in hand with the diffusion of democratic participation throughout society, including organisations (Lewin, 1936; Lewin, 1943; Lewin, 1946; Marrow, 1969).

Burnes and By (2012) made a strong case for the Planned approach to change having a greater emphasis on ethics than the Emergent approach. For Lewin, trying to achieve change through coercion or trickery was both unethical and ineffective. Instead, he argued for an ethical approach to change that promotes honest dialogue and full participation. Lewin's approach to change was based on Gestalt psychology and promoted individual and collective learning as being essential to successful change (Lewin 1942; Rock and Palmer 1990). Through learning about themselves and their situation, change participants at all organisational levels understand why they behave as they do and are enabled to judge what is and what is not appropriate behaviour (Bigge, 1982). Thus, from Lewin's Gestalt 
perspective, change and learning are intertwined, and form a cyclical sequence of iterations that allow participants to understand and change their situation in such a way that it becomes self-sustaining (i.e. safe from regression).

Lewin was initially concerned with identifying solutions to societal problems such as racism, but acknowledged that his approach could be applied to organisational issues (Burnes, 2007). Then, as now, the vast majority of organisational challenges revolved around the human side of the organisation, which is what his Planned approach to change was designed to address (Burnes, 2004, Marrow, 1969, Schein, 1988). Lewin saw the collaborative nature of Planned change, with its emphasis on everyone affected by the proposed change being involved, as an effective way for organisations to identify the root cause of a challenge and jointly attend to it.

\section{Remembering Burns}

Burns' (1978) Leadership was exceptionally well received within the leadership studies community (see Bennis, 1982 book review), and both critical and more mainstream leadership scholars (Evans et al, 2013; Gill, 2011) still frequently cite the book. Burns' purpose was to highlight a crisis of leadership, with the fundamental crisis underlying mediocrity being intellectual. He was troubled by the actions of formal leaders, but equally the inaction of those studying leadership. We would argue that despite three decades of transformation and change leadership discourse, leadership is still in crisis.

Burns championed an increased role for followers in leadership theory and practice. He emphasised dissensus echoing the creative destruction of innovation theorists (with Burns even citing Joseph Schumpeter). Burns (1978: 454) believed that "conflict unifies people just as it divides them" and suggested that "it would probably be better for most organisations, including corporations, unions, and university faculties, for dissensus to be built into their structures" (Burns, 1978: 453). This view disrupts the unitary beliefs of human resource departments and strategic planners characterising today's organisations. Burns's (1978) emphasised leadership as a symbiotic relationship between leaders and followers. In beginning to reimagine organisational change leadership we see a bridge between Burns' (1978) vision and Oreg et al's (2011) findings that employee participation is related to perceived procedural justice and trust in those leading change.

In seeking to further explain the respective contributions of Lewin and Burns to organisational change leadership, their contributions are compared and contrasted in Figure 1.

\begin{tabular}{|l|l|l|}
\hline $\begin{array}{l}\text { Compare and } \\
\text { Contrast }\end{array}$ & Lewin (1947a and b) & Burns (1978) \\
\hline Academic Discipline & Psychology & Political Science \\
\hline Focus/Motivation & $\begin{array}{l}\text { Helping the disadvantaged } \\
\text { and disenfranchised }\end{array}$ & $\begin{array}{l}\text { A belief in leadership transforming } \\
\text { societies and institutions }\end{array}$ \\
\hline
\end{tabular}




\begin{tabular}{|l|l|l|}
\hline $\begin{array}{l}\text { Essential Pillars/ } \\
\text { Ingredients }\end{array}$ & $\begin{array}{l}\text { 1.Field Theory } \\
\text { 2.Group Dynamics } \\
\text { 3.Action Research } \\
\text { 4.Three-Step Model }\end{array}$ & $\begin{array}{l}\text { 1.Symbiotic/collective relationship } \\
\text { between leaders and followers } \\
\text { 2.Distingushing transformational from } \\
\text { transactional leadership }\end{array}$ \\
\hline Managerial Focus & Not Interested & Not Interested \\
\hline Values/Ethics & Strong & $\begin{array}{l}\text { 'Moral leadership emerges from and } \\
\text { always returns to the fundamental } \\
\text { wants and needs, aspirations, and } \\
\text { values of the followers.' (Burns, 1978:4) }\end{array}$ \\
\hline $\begin{array}{l}\text { Understanding } \\
\text { Resistance to } \\
\text { Organizational } \\
\text { Change }\end{array}$ & $\begin{array}{l}\text { Resistance understood in } \\
\text { terms of field theory } \\
\text { (later translated into } \\
\text { force field analysis) and } \\
\text { seen as arising from the } \\
\text { organizational context } \\
\text { and the way change is } \\
\text { managed. }\end{array}$ & $\begin{array}{l}\text { "Leadership is dissensual: that is, } \\
\text { without conflict (peacefully managed); } \\
\text { we would all be trapped in a false } \\
\text { utopian dream" (Bennis, 1982:204). }\end{array}$ \\
\hline Commendations & $\begin{array}{l}\text { Intellectual father of } \\
\text { applied behavioural } \\
\text { science (Schein, 1988), } \\
\text { and founder of the } \\
\text { Organization Development } \\
\text { movement (OD)). }\end{array}$ & $\begin{array}{l}\text { International Leadership Association - } \\
\text { Lifetime achievement award winner } \\
\text { (International Leadership Association, } \\
\text { 2008) }\end{array}$ \\
\hline
\end{tabular}

Figure 1 - Comparing and contrasting the contributions of Lewin (1947a and b) and Burns (1978).

\section{Comparing Lewin and Burns}

The following discussion is organised around the comparisons summarised in Figure 1. Lewin's (1947) contribution to the Planned approach to change was informed by his psychology background. Whilst Burns (1978) is remembered for his contribution to leadership, his background was in political science and he had a keen interest in American political history. Both scholars were interested in change as a means of making a positive difference to people's lives and in the wider society, although in a broader sense than organisational change. Lewin (1947) was an advocate for the disadvantaged and disenfranchised, and Burns (1978) believed that leadership processes could transform societies and institutions in the best interests of the majority, rather than the minority.

Although the writings of Lewin frequently feature as part of the curricula in Business and Management schools, his main focus was on resolving social conflict and helping the disadvantaged in society rather than being primarily aimed at managers and management students. In Leadership, Burns (1978) makes reference to management (17 references), although he more frequently refers to administration (27 references). However, his focus was not upon managers or leaders, but rather leadership at the institutional and societal levels. 
Burns' (1978) Leadership drew attention to the differences between transformational and transactional leadership. A distinction which also lays at the heart of Bass' (1985) conceptualisation of leadership. However, Burns' and Bass' visions of transformational leadership differ considerably. Burns (1978: 4) stresses that "moral leadership emerges from, and always returns to the fundamental wants and needs, aspirations, and values of the followers". For Burns (1978), transformational leadership occurs when people engage with others so that leaders and followers raise one another to higher levels of motivation and morality. Therefore, morality was integral to Burns' depiction of transforming leadership and, like Lewin, he saw democracy and participation as fundamental to the success of organisational change. Many argue that this emphasis upon morality and participation is missing from Bass' conception of transformational leadership (see Carey 1992 and Simola et al, 2010). This has resulted in leading writers on leadership, such as Yukl (1999) and Storey (2010) questioning the utility of transformational leadership as popularised by Bass.

Dent and Goldberg (1999: 25) note that the concept of 'resistance to change' arose from Lewin's work and that he "introduced the term as a systems concept, as a force affecting managers and [other] employees equally". Lewin's view of resistance to change, which is based on his concept of Field Theory and Gestalt psychology, stresses that context is crucial in shaping individual actions (Burnes and Cooke, 2013). Lewin's (1947a and b) Field Theory maintains that individual and group behaviour is shaped by a complex field of forces that generates a 'quasistationary equilibrium'. For Lewin, behavioural change only occurs if the forces in a field change. As Burnes (2015:100) maintains, Lewin's view was that "The way to change the forces in the field to achieve a desired outcome is not to attempt to impose change, but to encourage participative decision-making". Burns' (1978) belief in leadership as dissensual and conflict unifying people is intriguing and ahead of the times in which he was writing. Indeed, it is refreshing to see resistance to organisational change engaged with creatively and positively - even as a potential resource.

\section{Misrepresenting Lewin and Burns}

Whilst the historiography of change management (Cooke, 1999) and leadership (Grint, 2008) have been critically questioned, it offers a means to understand how the contributions of Lewin (1947a, b) and Burns (1978) have been misrepresented.

Cooke (1999) regarded the construction of change management as a political process whereby the dominant ideologies of the day tend to ignore, undermine or reshape research and practices that do not fit with their narratives. From the 1970s onwards, we have seen how the rise of neo-liberalist and free market ideologies have provided a fertile ground on which transformational leadership has grown. In reverse, from the 1940s, we saw how Cold War America, with its fear of communism, proved inhospitable to Lewin's more collaborative-democratic approach to change, which tended to be subsumed by a more individualisticmanagerialistic approach (Burnes and Cooke, 2012). This is why, as Cooke (1999) illustrated, many accounts of the work of Lewin (1974 a, b), Collier (1947 and 1963 ) and Schein (1988) have sought to depict their work in a way that reflects a managerialist paradigm. However, such depictions diverged from the scholars' original intentions. 
For Cooke (1999), historiographical processes work through our knowing of the past, being constructed through identifying some events as significant, and, by implication, others as not, giving these events particular meaning. In terms of leadership, Grint (2008) criticised the tendency of leadership researchers going 'forward to the past'. Instead, Grint (2008) advocated going 'back to the future' in order to discover how those futures are constructed by decision-makers, and consider the persuasive mechanisms that decision-makers use in making situations more tractable to their own preferred forms of authority.

In reimagining organisational change leadership, our ambition is to avoid going 'forward to the past' in terms of progressive accounts of organisational change which serve to maintain the status-quo orthodoxy in the name of changing. Instead we chose to go 'back to the future' in order to remember Lewin's (1947 a, b) and Burns' (1978) contributions and begin to understand how these contributions have been misrepresented in constructing a particular form of organisational change leadership. In terms of the historiographical processes Cooke (1999) highlighted, we are offering a different historical narrative underpinning reimagined organisational change leadership.

\section{Misrepresentation of Lewin}

As Pettigrew (2000: 245-6) notes, the debate between the Planned and Emergent approaches to change has served to direct attention towards the importance of change, but it have also raised misleading dichotomies, paradoxes and contradictions. Certainly, some of the attacks on Lewin's work in general and the Planned approach in particular have misrepresented his work (Burnes, 2004). For example, Kanter et al's (1992: 10) portrayal of Lewin's Three-Step Model of Change as seeing 'organisations as an ice cube' is not only a misunderstanding of that model, but also a failure to realise that Lewin never advocated using any one of his Four Pillars in isolation from the others (Burnes, 2015). In addition, the baseless 'battle' between the Planned and Emergent approaches is also misleading in that much of it is based on the assumption that there is one right way to change, something Lewin never claimed (Burnes, 1996). Neither did Lewin suggest that there ever is an end-point to the process of change. Hence, his reference to quasi-stationary equilibria (Lewin, 1947a:13): “Change and constancy are relative concepts; group life is never without change, merely differences in the amount and type of change exist." In fact, the Emergent approach, being a collection of different change methods presumably disagreeing with the Planned approach, is in itself abundant as the flawed assumptions it is based upon have been invalidated (Burnes, 2004). There is simply no need to further debate Planned versus Emergent approaches.

Many scholars and practitioners criticising Lewin's work fall short when it comes to providing evidence of an understanding of his theories. Indeed, in some cases, they fail to provide any evidence of having even read Lewin's work, referring to an oversimplified understanding of only one of the Pillars, namely the Three-Step Model (Burnes, 2004). It is of course easy to criticise what one does not understand, though, to be fair, Lewin's writing were not always as easy to understand as they might have been, as even his friends acknowledged (Marrow, 1969). In his quest for scientific respectability, he attempted to adopt physics 
with its mathematical rigour as the underpinning 'paradigm science' for his Field Theory, making it over-complex and somewhat impenetrable to both scholars and practitioners (Burnes and Cooke, 2013). However, when stripping away Lewin's maths from his theories, and revealing the Gestalt underpinnings, a clear, useful and integrated approach to change emerges.

As Burnes and Cooke (2012 and 2013) have shown, Lewin's work, and the OD field in general, has experienced something of a renaissance and global growth over the last ten years or so. Partly, this is because there is now a better understanding of the work, but also because its values are seen as aligning better with the major challenges facing organisations in the $21^{\text {st }}$ century, especially the need to promote ethical and sustainable behaviour.

\section{Misrepresentation of Burns}

Three decades later, what Burns (1978) was proposing still appears radical, but despite commendations what he was proposing has largely been ignored. Instead of symbiotic relationships between leaders and followers, we have 'strong' and individualistic leaders making 'tough' decisions apparently in the best interests of everyone. Instead of leadership embracing dissensus, resistance is depicted as something that leaders have to overcome. Instead of appreciating the power of discourse and the socially constructed nature of leadership language, psychological accounts of leader traits, competencies and capabilities are obsessed over (see Fairhurst, 2008 for further discussion). Whilst followers were at the heart of Burns' (1978) approach to leadership, this never became the orthodoxy. Uhl-Bien et al (2014) in their review of followers and followership believed that they had been given short shrift in leadership studies.

However, the greatest failing is in how the misinterpreted transformational leadership has been attributed to Burns (1978). What he was seeking to achieve was transformation of societies and institutions through moral leadership informed by followers, not primarily the transformation of subordinates as depicted in transformational leadership (see Bass, 1985). Downton (1973) originally coined the phrase transformational leadership in Rebel leadership: Commitment and charisma in the revolutionary process. Unsurprisingly, Downton's (1973) contribution is rarely acknowledged within leadership and organisation studies orthodoxy. It was Burns' (1978) differentiation between transformational and transactional leadership which brought transformational leadership to the mainstream of leadership and organisation studies. Burns (1978) in emphasising moral leadership emerging from and always returning to the fundamental wants and needs, aspirations and values of followers offered a handbrake on strong leadership agency. This handbrake might have limited leadership excesses in financial institutions believed to have fuelled the 2008 global financial recession (see Tourish, 2013; Knights and McCabe, 2015). Unfortunately, the version of transformational leadership which became the leadership and organisation studies orthodoxy was transformational leadership as envisaged by Bass (1985):

"More quantity is no longer enough; quality must improve dramatically. Leaders may help in bringing about a radical shift in attention. For instance, groups oriented toward traditional beliefs will be shifted so that they come to 
value modern approaches. The contextual framework may be changed by leaders" (Bass, 1985:4).

This quotation is taken from one of Bass' (1985) earliest accounts of transformational leadership in Leadership and performance beyond expectations. He referred to this book as an 'initial statement' and 'preliminary scaffolding'. In dedicating it to Burns, he acknowledged that he was indebted for his original ideas about transformational and transactional leadership. It is important to acknowledge that in this early exposition, Bass (1985:183) made a strong case for moral leadership in stating that "the well-being of organizational life is better served in the long run by moral leadership." However, the managerialism of this version of transformational leadership was evident within the earlier indented quotation and the title of the book. More worryingly, Bass (1985:74) wrote that "the coercive, bullying, stem winding, browbeating, aggressive, combative leader can sometimes obtain remarkable transformations" of subordinates (see Tourish and Pinnington, 2002 and Tourish, 2013 for further critiques of transformational leadership). Critical commentators have questioned the morality of the form of transformational leadership subsequently promoted (see Carey 1992; Yukl, 1999 and Simola et al, 2010 for further discussion and Khanin, 2007 for contrasts between Burns and Bass).

\section{Organisational change leadership reimagined}

Whilst not primarily writing about organisational change leadership, Lewin and Burns positively imagined utilitarian futures which benefitted the majority, rather than the minority. They believed that societies and organisations could be transformed into something better than the status quo. However, a mythical leadership narrative potentially explains why leadership orthodoxy has been so resistant to change, generating a mythological story of leadership which has been told over and over again and everyone seems to believe (Rost, 1993). Drawing on Edelman's (1971) symbolic theory of rewards, Rost showed how leadership research and scholarship was traditionally being presented (see Figure 2).

1. The organised study of leadership has been effective.

2. Our understanding of leadership has been enhanced by leadership researchers, which is what such scholars are supposed to do.

3. As such, both researchers and practitioners can take comfort from our increasingly erudite appreciation of leadership.

4. As a consequence, this better understanding of leadership will help make organisations more productive and, in the end, the United States and the world a better place to work and live.

Figure 2 - The mythological leadership studies narrative (based upon Rost, 1993) 
Rost (1993) regarded the mythological leadership studies narrative (Figure 2) as restricting alternative conceptualisations of leadership and imprisoning leadership researchers in an outdated and misleading paradigm (see also Gemmill and Oakley, 1992; Kelly, 2014). The sad irony within the mythological leadership studies narrative which Rost (1993) highlighted is that Lewin (1947, a, b) sought change for disadvantaged groups and Burns (1978) as a political scientist wanted to see societies and institutions transformed, yet leadership theory and practice itself appear unable to change. The present leadership mythology may even prevent the utilitarian societal improvements and developments both Lewin and Burns were seeking to achieve.

Imagining discursive and ambiguous, culturally informed organisational change leadership is challenging. In terms of transforming organisations through leadership, Hughes $(2015)$ identified Kotter $(1995,1996)$ as the most cited scholar, and the concept of transformational leadership has been described as the most debated idea in the field of leadership studies over the past thirty years (DiazSaenz, 2011). There are reasons to be sceptical about Kotter's (1996) eight leadership steps towards successful transformation (Hughes, 2015), and within the current leadership orthodoxy, transformational leadership is primarily concerned with the transformation of subordinates, not as often literally interpreted organisational transformation through leadership (Haslam et al, 2011). Moreover, the rewards from this approach are heavily geared towards formal leaders often at the (high) cost of other stakeholders. Indeed, others, as the 2008 financial crisis demonstrated, are often disproportionately disadvantaged. From a consequentialist perspective, one of the main criticisms of the transformational approach is that it encourages individual rather than utilitarian consequentialism. Whatever the merits of this approach in the past, in a world in which sustainability is required for survival, the pursuit of individual consequentialism will be disastrous for all of us, including our leaders. If, as Grint (2000) suggests, leadership is primarily rooted in and a product of the imagination, then the future survival of the planet requires us to reimagine leadership not as the selfish pursuit of individual or group gain, but the collective commitment to building sustainable organisations and societies - see Figure 3.

\begin{tabular}{|l|l|l|}
\hline & \multicolumn{1}{|c|}{$\begin{array}{c}\text { Current Organisational } \\
\text { Change Leadership }\end{array}$} & $\begin{array}{c}\text { Reimagined Organisational } \\
\text { Change Leadership }\end{array}$ \\
\hline Stakeholders & $\begin{array}{l}\text { Narrow interests groups, } \\
\text { powerful guiding coalitions }\end{array}$ & $\begin{array}{l}\text { Broad interests of society and } \\
\text { institutions }\end{array}$ \\
\hline Agency & $\begin{array}{l}\text { Strong, individualistic and } \\
\text { masculine }\end{array}$ & $\begin{array}{l}\text { Collaborative/collective, non- } \\
\text { gendered }\end{array}$ \\
\hline Ethics & $\begin{array}{l}\text { Rhetorical platitudes geared } \\
\text { towards individual } \\
\text { consequentialism }\end{array}$ & $\begin{array}{l}\text { Moral leadership through } \\
\text { leader/follower engagement } \\
\text { geared towards utilitarian } \\
\text { consequentialism }\end{array}$ \\
\hline
\end{tabular}




\begin{tabular}{|l|l|l|}
\hline Role of Dissensus & $\begin{array}{l}\text { Resistance to organisational } \\
\text { change as something which has } \\
\text { to be overcome }\end{array}$ & $\begin{array}{l}\text { Responses of subordinates } \\
\text { informative, dissensus is } \\
\text { creative }\end{array}$ \\
\hline Academic Disciplines & $\begin{array}{l}\text { Management and Organisation } \\
\text { studies }\end{array}$ & $\begin{array}{l}\text { Interdisciplinary and } \\
\text { multidisciplinary }\end{array}$ \\
\hline Differentiations & $\begin{array}{l}\text { Leadership differentiated from } \\
\text { management and privileged } \\
\text { over management }\end{array}$ & $\begin{array}{l}\text { Leadership and management as } \\
\text { interdependent }\end{array}$ \\
\hline Role of Research & $\begin{array}{l}\text { Meaningful research findings } \\
\text { illusive and conducting } \\
\text { research problematic }\end{array}$ & Action research \\
\hline
\end{tabular}

Figure 3 - Organisational change leadership reimagined

The first column in Figure 3 is an intentionally caricatured depiction of how we might currently imagine organisational change leadership. The contrast with the caricature helps to reimagine organisational change leadership in the second column which is informed by the readings of Lewin (1947a, b) and Burns (1978) featured here. We offer no references in support of either column, instead favouring the creative playfulness of imagining (Wright Mills, 1959).

Organisational change leadership reimagined is concerned with broader interests of ethics and what is in the interest of the wider society and organisations within it, rather than narrow sectional and individual interests of leaders. Organisational change leadership reimagined emphasises the collective and collaborative and no longer exclusively masculine agency of leaders working with followers and collaborators, rather than the agency of 'strong' and individualistic leaders. Distributed leadership agency offers greater ethical safeguards than the current platitudes and rhetorical mission and value statements organisations so proudly promote. Organisational change leadership reimagined regards the views and opinions of all organisational members as informative and dissensus as creative, rather than depicting such people as resistors who have to be overcome.

Organisational change leadership reimagined draws upon multiple academic disciplines and their interrelationships, rather than privileging the contribution of leadership, management and organisation studies. Organisational change leadership reimagined regards leadership and management as interdependent and is suspicious of the current fashionable privileging of leadership as superior to management. Organisational change leadership reimagined through engaging with all organisational members opens up opportunities for action research so that participants in change can be part of processes of researching and changing, bringing to an end the search for empirical findings to support the spurious dominant orthodoxy. 


\section{Conclusions}

In this article we have set out to identify a utilitarian consequentialist organisational change leadership orthodoxy as an alternative to the status quo. We related this to the work of Lewin (1947, a, b) and Burns (1978) who dared to dream of an approach to organisational change leadership that in Bentham's words (Jones, 1980:368) is all about enabling 'the greatest good for the greatest number'. Through their polemical writings, and in Lewin's case his actual practice (Burnes, 2004), both Lewin and Burns encouraged others to share their dream which in essence is what organisational change leadership is all about. In creatively reimagining organisational change leadership we have shared their philosophies and celebrated their contributions. However, organisational writing about leadership "...maintains a specific set of practices and discourses in place the basic power relations network on which 'leadership' has been constituted and re-constituted" (Calas and Smircich, 1991:569). In reimagining organisational change leadership it is ironic how resistant to change the status quo has been. Once again, Calas and Smircich, (1991:568) were ahead of us when suggesting that for leadership "...the more things change, the more they remain the same."

\section{References}

Arnold, D.G., Goodpaster, K.E. and Weaver, G.E. 2015. From the Editors: Past trends and future directions in business ethics and corporate responsibility scholarship. Business Ethics Quarterly, 25: V-XV.

Baggini, J. and Fosl, P.S. 2007. The ethics toolkit: A compendium of ethical concepts and methods. Oxford: Blackwell

Bass, B.M. 1985. Leadership and performance beyond expectations. New York: Free Press.

Bennis, W. 1982. Book review of Leadership by J.M. Burns. American Journal of Sociology, 88: 202-205.

Bigge, L.M. 1982. Learning theories for teachers. Aldershot: Gower.

Blackburn, S. 2008. The Oxford dictionary of philosophy (2 ${ }^{\text {nd }}$ Edition). Oxford: OUP.

Burnes, B. 1996. No such thing as ... a "one best way" to manage organizational change, Management Decision, 34: 11 - 18.

Burnes, B. 2004. Kurt Lewin and the planned approach to change: A re-appraisal. Journal of Management Studies, 41: 977-1002.

Burnes, B. 2007. Kurt Lewin and the Harwood studies: the foundations of OD. Journal of Applied Behavioral Science, 43: 213 - 231. 
Burnes, B. 2009. Reflections: Ethics and organisational change - time for a return to

Lewinian values. Journal of Change Management, 9: 359-381.

Burnes, B. 2014. Managing change (6 $6^{\text {th }}$ Edition). Harlow: Pearson.

Burnes, B. 2015. Understanding resistance to change - Building on Coch and French. Journal of Change Management, 15: 92-116.

Burnes, B. and By, R.T. 2012. Ethics, leadership and change: The case for greater clarity. Journal of Business Ethics, 108: 239-252.

Burnes, B and Cooke, B. 2012. Review article: The past, present and future of organization development: Taking the long view. Human Relations, 65: 13951429.

Burnes, B. and Cooke, B. 2013. Kurt Lewin's field theory: A review and reevaluation. International Journal of Management Reviews, 15: 408-425.

Burnes, B. and Jackson, P. 2011. Success and failure in organisational change: An exploration of the role of values. Journal of Change Management, 11: 133162.

Burns, J.M. 1978. Leadership. New York: Harper Row Publishers.

By, R. T. 2005. Organisational change management: A critical review. Journal of Change Management, 5: 369-380.

By, R.T. and Burnes, B. (Eds.). 2013. Organizational change, leadership and ethics: Leading organizations towards sustainability. London: Routledge.

By, R.T., Hughes, M., and Ford, J. 2016. Change leadership: Oxymoron and myths. Journal of Change Management, 16: 8-17.

By, R.T. and Macleod, C. (Eds.). 2009. Managing organizational change in public services. London: Routledge.

Calas, M.B. and Smircich, L. 1991. Voicing seduction to silence leadership. Organization Studies, 12: 567-602.

Carey, M.R. 1992. Transformational leadership and fundamental option for self transcendence. The Leadership Quarterly, 3: 217-236.

Ciulla, J.B. 2008. Leadership studies and "the fusion of horizons." The Leadership Quarterly, 19: 393-395.

Collier, J. 1947. America's colonial record. London: Fabian Publications. 
Collier, J. 1963. From every zenith. Denver: Sage Books.

Comte, A (1875) The positive philosophy of Auguste Comte (2 ${ }^{\text {nd }}$ Edition). London: Trubner.

Conner, P.E. 1977. A critical enquiry into some assumptions and values characterizing OD. Academy of Management Review, 2: 635 - 44.

Cooke, B. 1999. Writing the left out of management theory: The historiography of the management of change. Organization, 6: 81-105.

Crump, R. 2014. FTSE 100 CFO turnover reaches post-financial crisis peak. Financial

Director, 26 November. Available at financialdirector.co.uk. Accessed 16 May 2016.

Diaz-Saenz, H.R. 2011. Transformational leadership. In Bryman, A., D. Collinson. K. Grint. B. Jackson and M. Uhl-Bien (Eds.), The SAGE handbook of leadership: 299-310. London: Sage Publications Ltd.

Dent, E.B. 2002. The messy history of OBandD: How three strands came to be seen as one rope. Management Decision, 40: 266-80.

Dent, E.B. and Goldberg, S.G. 1999. Challenging resistance to change. Journal of Applied Behavioral Science, 35: 25-41.

Downton, J.V. 1973. Rebel leadership: Commitment and charisma in the revolutionary process. New York: Free Press.

Dunphy, D.D. and Griffiths, A. 1998. The sustainable corporation: Organisational renewal in Australia. St Leonards, Australia: Allen and Unwin.

Dunphy, D., Griffiths, A. and Benn, S. 2007. Organizational change for corporate sustainability. London: Routledge.

Edelman, M. 1971. Politics are symbolic actions. Chicago: Markham.

Elkington, J. 1999. Cannibals with forks: Triple bottom line of 21st century business. North Mankato, MN: Capstone

Evans, P., Hassard, J. and Hyde, P. 2013. Critical leadership: Leader-follower dynamics in a public organization. Routledge critical studies in public management. London: Routledge.

Fairhurst, G.T. 2008. Discursive leadership: A communication alternative to leadership psychology. Management Communication Quarterly, 21: 510-521. 
French, W.L. and Bell, C.H. 1973. Organization development. Englewood Cliffs, NJ: Prentice-Hall.

French, W.L. and Bell, C.H. 1995. Organization development (5th edition). Englewood Cliffs, NJ: Prentice-Hall.

French, W.L. and Bell, C.H. 1999. Organization development (6th edition). Upper Saddle River, NJ: Prentice-Hall.

Ford, J. D. and Ford, L.W. 2012. The leadership of change: A view from recent empirical evidence. In Pasmore, W., Woodman, R. and Shani, A. (Eds.), Research in Organization Change and Development, 20: 1-36.

Gellerman, W., Frankel, M.S. and Ladenson, R.F. 1990. Values and ethics in organizational and human systems development: Responding to dilemmas in professional life. San Francisco, CA: Jossey-Bass.

Gemmill, G., and Oakley, G. 1992. Leadership: An alienating social myth. Human Relations, 45:113-129.

Gill, R. 2011. Theory and practice of leadership. London: Sage Publications Ltd.

Gilley, A; McMillan, H. S.; and Gilley, J. W. (2015). Organizational Change and Characteristics of leadership Effectiveness. In C. Dumas and R. H. Beinecke (Eds): Change Leadership. Los Angeles, CA.: SAGE.

Gold, S.; Hahn, R.; and Seuring, S. (2013). Sustainable supply chain management in "Base of the Pyramid" food projects-A path to triple bottom line approaches for multinationals? International Business Review, 22 (5), 748-799.

Goldenberg, S. 2010. United States sues BP over Gulf oil disaster. The Guardian, 16 December, available at www.guardian.co.uk

Goldworth, A (Ed). 1983. The collected works of Jeremy Bentham: Deontology. Together with a table of the springs of action and article on utilitarianism. Oxford: Clarendon Press.

Gopalakrishnan, S., Mangaliso, M.P., and Butterfield, D.A. 2008. Managing ethically in times of transformation challenges and opportunities. Group and Organization Management, 33: 756-759.

Grint, K. 2008. Forward to the past or back to the future? Leadership, 1965-2006. In S, Dopson., M, Earl, and P. Snow (Eds.), Mapping the management journey: Practice, theory and context: 104-18. Oxford: Oxford University Press.

Hamilton, C (2016) How scared or hopeful should we be in a warming world? The Guardian, 12 May. Available at theguardian.com. Accesses 14 may 2016. 
Hasina, S. 2016. Climate Change after Paris: Developed Nations Must do Their Part. U.S.

News and World Report, 18 January. Available at http://www.usnews.com/news/the-

report/articles/2016-01-18/climate-change-after-paris.

Haslam, S.A., S.D. Reicher and Platlow, M.J. 2011. The new psychology of leadership: Identity influence and power. Hove: Psychology Press.

Highhouse S. 2007. Applications of organizational psychology: Learning through failure or failure to learn? In Koppes L.L. (Ed.), Historical perspectives in industrial and organizational psychology. Mahwah, NJ: Lawrence Erlbaum.

Hollander, E.P. 1995. Ethical challenges in the leader-follower relationship. Business Ethics Quarterly, 5: 55-65.

Hughes, M. 2015. The leadership of organizational change. London: Routledge.

Hughes, M. forthcoming. Leading changes: Why transformation explanations fail? Leadership.

Hurley, R.F., Church, A.H., Burke, W.W. and Van Eynde, D.F. 1992. Tension, change and values in OD. OD Practitioner, 29: 1-5.

International Leadership Association 2008. James MacGregor Burns - Lifetime Achievement Award Winner. http://www.ilanet.org/LeadershipLegacy/James_MacGregor_Burns.html

Jenkins, P (2016) Financials - Executive Pay - Reform vital to 'restore faith in capitalism'.

Financial Times, 9 May. Available at ftsyndication.com. Accessed 12 May 2016.

Jones, G.R., George, J.M., and Hill, C.W.L. 2000. Contemporary management. Boston, MA: McGraw Hill.

Jones, W. T. (1980). Masters of political thought (Volume 2): Machiavelli to Bentham. London: Harrap.

Kagan, S. 1992. The structure of normative ethics. Philosophical Perspectives, 6: 223-242.

Kaler, J. 2000a. Positioning business ethics in relation to management and political philosophy. Journal of Business Ethics, 24: 257 - 272.

Kaler, J. 2000b. Reasons to be ethical: Self-interest and ethical business. Journal of Business Ethics, 27: 161 - 173. 
Kanter, R.M., Stein, B.A. and Jick, T.D. 1992. The challenge of organizational change. Free Press: New York, NY.

Kelly, S. 2014. Towards a negative ontology of leadership. Human Relations, 67: 905-922.

Kets de Vries, M.F.R. 2009. Reflections on character and leadership. San Francisco, CA: Jossey-Bass.

Khanin, D. 2007. Contrasting Burns and Bass: Does the transactional transformational

paradigm live up to Burns's philosophy of transforming leadership? Journal of Leadership Studies, 1: 7-25

Knights, D. and McCabe, D. 2015. 'Masters of the Universe': Demystifying leadership in the context of the 2008 global financial recession. British Journal of Management, 26:197-210.

Kotter, J.P. 1995. Leading change: Why transformation efforts fail. Harvard Business Review, 73: 259-67.

Kotter, J.P. 1996. Leading change. Boston: Harvard Business School Press.

Kotter, J. P. 1990. A force for change: How leadership differs from management. New York: Free Press.

Lewin, K. 1936. Some social-psychological differences between the United States and Germany. In Lewin G.W. (Ed.), Resolving social conflict: 3-33. London: Harper and Row.

Lewin, K. 1942. Field theory and learning. In D.Cartwright (Ed), Field theory in social science: Selected theoretical papers by Kurt Lewin: 60-86. London: Social Science Paperbacks.

Lewin, K. 1943. The special case of Germany. In Lewin G.W. (Ed.), Resolving social conflict: 43-55. London: Harper and Row.

Lewin, K. 1946. Action research and minority problems. In Lewin G.W. (Ed.), Resolving Social Conflict: 201-220. London: Harper and Row.

Lewin, K. 1947a. Frontiers in group dynamics: Concept, method and reality in social sciences; social equilibria and social change. Human Relations, 1(1): 5-41.

Lewin, K. 1947b. Frontiers in group dynamics II: Channels for group life; Social planning and action research. Human Relations, 1: 143-153.

Lewin, K., Lippitt, R. and White, R.K. 1939. Patterns of aggressive behavior in experimentally created social climates. Journal of Social Psychology, 10: 271299. 
Locke, J. 1958. Essays on the law of nature. Oxford: Clarendon Press.

Lund-Thomsen, P. and Lindgreen, A. 2014. Corporate social responsibility in global value chains: Where are we now and where are we going? Journal of Business Ethics, 123: 11-22.

March, J.G. 1981. Footnotes to organizational change. Administrative Science Quarterly, 26: 563-577.

Marrow, A.J. 1969. The practical theorist: The life and work of Kurt Lewin. New York, NY: Teachers College Press.

Mertens, J-F. and Dhillon, A. 1999. Relative utilitarianism. Econometrica, 67: 471498.

Mill, J.S. 2002. Utilitarianism (2 ${ }^{\text {nd }}$ Ed). Indianapolis: Hackett Publishing.

Mirvis, P.H. 2006. Revolutions in OD: The new and the new, new Things. In J.V. Gallos

(Ed.), Organization development: A Jossey-Bass reader: 39-88. San

Francisco, CA: Jossey-Bass.

Mooney, B. 2004. Shaping history: 100 great leaders - from antiquity to the present.

London: Arcturus Foulsham.

Oreg, S., Vakola, M. and Armenakis, A. 2011. Change recipients' reactions to organizational change: a 60-year review of quantitative studies. Journal of Applied Behavioral

Science, 47: 461-524.

Parry, K.W. 2011. Leadership and organization theory. In A. Bryman., D. Collinson. K. Grint. B. Jackson and M. Uhl-Bien (Eds.), The SAGE handbook of leadership: 53-70. London: Sage Publications Ltd.

Pettit, P. 2003. Consequentialism. In S. Darwall (Ed.), Consequentialism. Oxford: Blackwell.

Pettigrew, AM (2000) Linking change processes and outcomes: a commentary on Ghosal, Bartlett and Weick. In M.Beer and N.Nohria (eds): Breaking the code of change. Boston, MA: Harvard Business School Press.

Pursey, P.M., Heugens, A.R., and Scherer, A.G. 2010. When organization theory met business ethics: Toward further symbioses. Business Ethics Quarterly, 20:643-672.

Porras, J.I. and Bradford, D.L. 2004. A historical view of the future of OD: An interview with Jerry Porras. Journal of Applied Behavioral Science, 40: 392-402. 
Rock, I. and Palmer, S. 1990. The legacy of gestalt psychology. Scientific America, December, 48-61.

Rost, J.C. 1993. Leadership for the twenty-first century. Westport, CT: Praeger.

Savitz, A.W. and Weber, K. (2014) Triple Bottom Line. San Francisco, CA: Jossey-Bass.

Schein E.H. 1988. Organizational Psychology (3 ${ }^{\text {rd }}$ Edition). Englewoods Cliffs:

Prentice

Hall.

Sidgwick, H. 1981. Methods of ethics (7th Edition). : Indianapolis: Hackett Publishing

Simola, S.K., J. Barling and Turner, N. 2010. Transformational leadership and leader moral orientation: Contrasting an ethic of justice and an ethic of care. The Leadership Quarterly, 21: 179-188.

Stiglitz, J. 2010. Freefall: Free markets and the sinking of the global economy. London: Allen Lane.

Storey, J. 2010. Signs of change: 'Damned Rascals' and beyond. In J. Storey (Ed.), Leadership in organizations: Current issues and key trends: 3-13. London: Routledge.

Thiroux, J.P. and Krasemann, K.W. 2007. Ethics: Theory and practice (9th Edition). Upper Saddle River, NJ: Pearson Prentice Hill.

Tourish, D. 2013. The dark side of transformational leadership. Hove: Routledge.

Tourish, D., and Pinnington, A. 2002. Transformational leadership, corporate cultism and

the spirituality paradigm: An unholy trinity in the workplace. Human Relations, 55: $147-172$.

Uhl-Bien, M., Riggio, R.E., Lowe, K.B. and Carsten, M.K., 2014. Followership theory: A review and research agenda. The Leadership Quarterly, 25(1), pp.83104.

Warwick, D.P. and Thompson, J.T. 1980. Still crazy after all these years. Training and Development Journal, 34: 16 - 22.

Wearden, G., Teather, D. and Treanor, J. 2008. Banking crisis: Lehman Brothers files for bankruptcy protection. The Guardian, 15 September, available at www.guardian.co.uk

Wellesley, L., Happer, C. and Froggatt, A. 2015. Changing climate, changing diets: pathway to lower meat consumption: Chatham House Report, November. London: The Royal Institute of International Affairs. 
Willard, B. (2012). The New Sustainability Advantage. Gibrolia Island, Canada: New Society Publishers.

Wines, W.A. 2008. Seven pillars of business ethics: Toward a comprehensive framework. Journal of Business Ethics, 79: 483 - 499.

Wirtenberg J. Abrams, L. and Ott, C. 2004. Assessing the field of organization development. Journal of Applied Behavioral Science, 40: 465-479.

Wirtenberg J., Lipsky D., Abrams L., Conway M. and Slepian J. 2007. The future of organization development: Enabling sustainable business performance through people. Organization Development Journal, 25: 7-22.

Wood-Harper, T., Corder, S., Wood, J.R.G. and Watson, H. 1996. How we profess: The ethical systems analyst. Communications of the ACM, 39: 69-77.

Wright Mills, C. 1959. The sociological imagination. New York: Oxford University Press.

Yukl, G. 1999. An evaluation of conceptual weaknesses in transformational and charismatic leadership theories. The Leadership Quarterly, 10: 285-305.

Zand, D.E. 2010. An OD odyssey: In search of inward light. Journal of Applied Behavioral

Science, 46: 424-435. 


\section{Appendix 1}

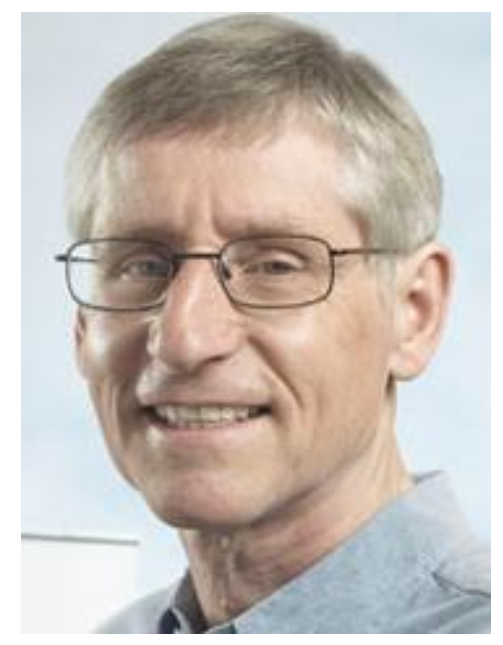

Bernard Burnes is Professor of Organisational Change (Stirling Management School, UK) and is one of the leading international authorities on organisational change. Bernard is the author of over 50 journal articles, over 20 books and around 40 book chapters. He is the author of Managing Change (6th edition, 2014), the best-selling European textbook in the field, Editor of the Routledge book series Understanding Organizational Change, Joint Editor of the Routledge Companion to Organizational Change, and Associate Editor of the Journal of Change Management. His article 'Kurt Lewin and the Planned Approach to Change: A Re-appraisal' (Journal of Management Studies), received a Citation of Excellence as one of the top 50 management articles in the world in 2004, has been reprinted twice and has received over 250 citations.

Email: bernard.burnes@stir.ac.uk

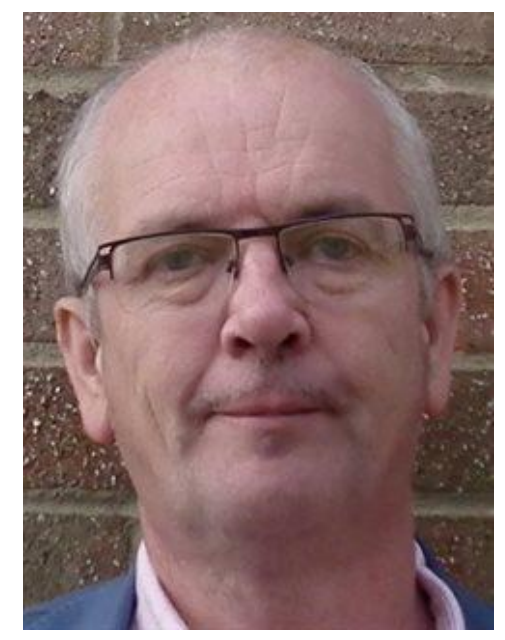

Mark Hughes is Reader in Organisational Change (University of Brighton Business School, UK) with all of his research, teaching, scholarship and external engagement focusing upon this field. He is the Deputy Director of the Centre for Research on Management and Employment (CROME) and a member of the Editorial Board for the Journal of Change Management. Mark is the author of Managing Change: A Critical Perspective (2nd edition, 2010).

Email: M.A.Hughes@brighton.ac.uk 


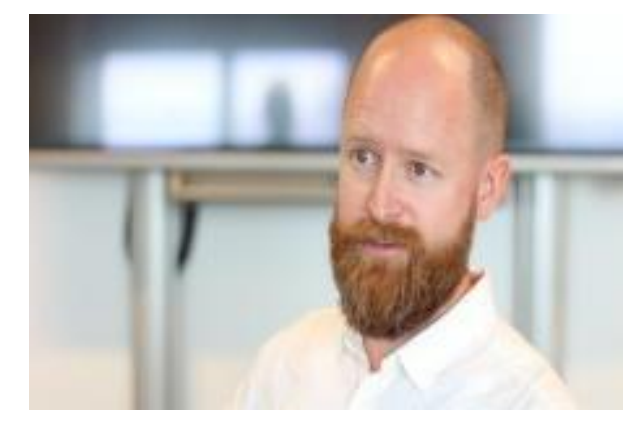

Rune Todnem By* is Professor of Organisational Behaviour (Staffordshire University Business School, UK), Professor II Change Leadership (University of Stavanger, Norway) and Co-founder and Chair of the Public Leadership Foundation. $\mathrm{He}$ is the Editor-in-Chief of Journal of Change Management, co-author of Managing Change in Organizations (6th edition, 2014), and co-editor of The Psychology of Organizational Change: Viewing Change from the Employee's Perspective; Organizational Change, Leadership and Ethics; and Managing Organizational Change in Public Services. Rune is consistently identified as being in the top $0.1 \%$ of scholars registered on academia.edu.

Email: r.t.by@staffs.ac.uk

*Corresponding author:

Professor Rune Todnem By

Staffordshire University Business School

Brindley Building

Leek Road

Stoke-on-Trent

ST4 2DF

UK 